\title{
АНАЛІЗ ПРОБИ МАКСИМАЛЬНОЇ ВЕНТИЛЯЦІЇ ЛЕГЕНІВ ПРИ ДОДАТКОВОМУ ОПОРІ ДИХАННЮ
}

\author{
С. О. Коваленко, С. В. Гречуха, Л. І. Кудій \\ Черкаський національний університет імені Богдана Хмельницького
}

\begin{abstract}
У вимірюваннях на 26 здорових молодих чоловіках (15 спортсменах-веслувальниках та 11 неспортсменах) за оригінальною комп'ютерною програмою проводили аналіз пневмограм дихання впродовж тесту максимальної вентиляції легенів без та з додатковим опором вдиху та видиху 25 см вод. ст.-л-с ${ }^{-1}$. У спортсменів пробу повторювали від 2 до 5 разів через проміжки часу від 6 до 86 днів (у середньому $(41,4 \pm 3,61)$ дня) перед виконанням тренувальних занять. При цьому вимірювали рівень частоти дихання, дихальний об'єм, швидкість та прискорення повітряного потоку на вдиху й видиху та їх динаміку впродовж проби. У спортсменів за всіх умов спостерігали вищий рівень швидкості руху повітря на видиху, його прискорення на вдиху та видиху, хвилинний об'єм дихання. За результатами кореляційного аналізу при повторних вимірюваннях встановлено, що найбільш надійною є оцінка показників при проведенні тесту з опором вдиху та видиху та їх динаміки впродовж проби з опором вдиху.
\end{abstract}

Ключові слова: максимальна вентиляція легенів, опір диханню.

\section{АНАЛИЗ ПРОБЫ МАКСИМАЛЬНОЙ ВЕНТИЛЯЦИИ ЛЕГКИХ ПРИ ДОПОЛНИТЕЛЬНОМ СОПРОТИВЛЕНИИ ДЫХАНИЮ}

\author{
С. А. Коваленко, С. В. Гречуха, Л. И. Кудий \\ Черкасский национальный университет имени Богдана Хмельницкого
}

\begin{abstract}
В измерениях на 26 здоровых молодых мужчинах (15 спортсменах-гребцах и 11 неспортсменах) в оригинальной компьютерной программе проводили анализ пневмограмм дыхания, зарегистрированных на протяжении теста максимальной вентиляции легких без и с дополнительным сопротивлением вдоху и выдоху 25 см вод. ст.-л-с ${ }^{-1}$. У спортсме-

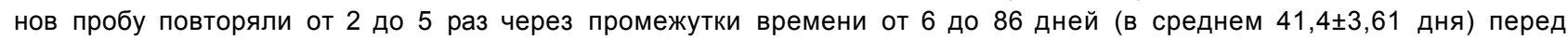
выполнением тренировочных занятий. При этом выясняли уровень частоты дыхания, дыхательного объема, скорости и ускорения воздушного потока на вдохе и выдохе и их динамику на протяжении пробы. У спортсменов при всех условиях наблюдался выше уровень скорости движения воздуха на выдохе, его ускорения на вдохе и выдохе, минутного объема дыхания. Сравнение динамики спирографических показателей в группах обследуемых на протяжении теста показало, что без дополнительного сопротивления медианы процента изменений на 7-9 секундах от его начала в сравнении с 1-3 секундами не отличались. При дополнительном сопротивлении наблюдалось достоверно большее снижение почти всех анализируемых показателей в группе спортсменов, что может свидетельствовать о более быстром врабатывании дыхательных мышц у них в начале нагрузки. По результатам корреляционного анализа при повторных измерениях установлено, что наиболее надежной является оценка показателей при проведении теста с сопротивлением вдоху и выдоху и их динамики на протяжении пробы с сопротивлением вдоху.
\end{abstract}

Ключевые слова: максимальная вентиляция легких, сопротивление дыханию.

\section{PROBE ANALYSIS OF LUNGS MAXIMUM VENTILATION WITH ADDITIONAL RESPIRATION RESISTANCE}

\author{
S. O. Kovalenko, S. V. Hrechukha, L. I. Kudiy \\ Cherkasy National University by Bohdan Khmelnytskyi
}

\begin{abstract}
Respiration pneumograms registered during testing maximum lungs ventilation without and with additional resistance to inhale and exhale $25 \mathrm{~cm}$ of w. c. $-1-\mathrm{s}^{-1}$ were analyzed in original computer program while examining 26 healthy young men (15 sportsmen - rowers and 11 non-sportsmen). The probe was repeated from 2 till 5 times in time lapses from 6 till 86 days $(41,4 \pm 3,61$ days in average) before performing training sets by the sportsmen. The level of respiration frequency, respiration volume, speed and acceleration of airflow were found on inhale and exhale and their dynamics during the probe.

The level of air movement speed on exhale, its acceleration on inhale and exhale, minute volume of respiration was found higher among the sportsmen under all the conditions. The comparison of spirograph indexes in the examined groups
\end{abstract}

(C) С. О. Коваленко, С. В. Гречуха, Л. І. Кудій 


\section{МЕДИЧНА ІНФОРМАТИКА TA IHЖЕНЕРIЯ}

during the test showed that without additional resistance the medians of per cent change on 7-9 seconds from its beginning did not differ if compared with 1-3 seconds. The reliably higher decrease of almost all analyzed indexes in the group of sportsmen was found with additional resistance that might show faster work of respiration muscles at the beginning of loading. The results of correlation analysis with repeated tests showed that the most reliable index was the estimation of indexes while testing inhale and exhale resistance and their dynamics during the probe with inhale resistance.

Key words: maximum lungs ventilation, respiration resistance.

Вступ. Максимальна вентиляція легень (МВЛ) це гранично можлива кількість повітря, яке може бути провентильоване через легені за одиницю часу. Цей показник залежить від функціонального стану системи зовнішнього дихання людини, стійкості дихального центру до гіпокапнії, мотивації обстежуваного до проведення вимірювань [1]. Відмічено, що МВЛ може змінюватись у процесі тренування [2, 3], за різних умов середовища [4], а також відрізняється у спортсменів різної спеціалізації та у неспортсменів [5]. За допомогою додаткових експериментальних методик можливе визначення функціонального стану дихальних м'язів при виконанні тесту МВЛ [6]. Втім, деякі автори вважають, що великі коливання МВЛ знижують діагностичну цінність визначення абсолютної величини даного параметра [7].

Показник МВЛ розглядають як одну із складових способів оцінки резервних можливостей організму [8] та порушень функціонування системи зовнішнього дихання [9]. Технічних рішень, i, тим більше, автоматизованих систем оцінки функціонального стану людини за окремими параметрами пневмограми, їх динаміки під час виконання тесту за умов додаткового опору диханню досі немас. Необхідність такого підходу обумовлюється широким застосуванням ком п 'ютерної пневмометрії з можливістю кількісної оцінки ії характеристик та створенням на базі цього нових методик функціональної діагностики.

Тому розробка системи оцінювання функціонального стану людини, зокрема показників зовнішнього дихання, на основі детальних характеристик пневмограми під час проведення тесту МВЛ із різним опором диханню, може підвищити практичну цінність їх визначення та відкрити нові напрямки в превентивній терапії та функціональній діагностиці.

Мета дослідження. З'ясувати валідність i надійність оцінки спірографічних показників, отриманих під час тесту максимальної вентиляції легенів без і з додатковим опором диханню.

Матеріал і методи дослідження. Вимірювання здійснені на 26 здорових молодих чоловіках віком 18 32 років у спокої сидячи. 3 них 15 осіб тренувались у веслуванні на байдарках і каное та мали високі спортивні розряди, а 11 - були студентами ВНЗ, і не займались регулярними фізичними вправами. Пробу МВЛ проводили впродовж 10 секунд без додаткового опору диханню, 3 додатковим опором видиху та вдиху 25 смвод.ст.лс ${ }^{-1}$. У спортсменів пробу повторювали від 2 до 5 разів через проміжки часу від 6 до 86 днів (у середньому $(41,4 \pm 3,61)$ дня) перед виконанням тренувальних занять. Пневмограму реєстрували на комп'ютерному спірографі Spirocom Standard (XAI-медика, Харків, Україна). Записи швидкості повітряного потоку, які були оцифровані з дискретизацією 100 Гц, обробляли у програмній системі LVV-meter (a/ с України J№ 41075), розробленій нами. Після цього за кожним із послідовних спіроциклів визначали наступні показники: дихальний об'єм (ДО), як площу над і під кривою швидкості повітряного потоку відповідно на вдиху $\left(\mathrm{S}_{\mathrm{vd}}\right)$ та видиху $\left(\mathrm{S}_{\mathrm{vud}}\right)$, поділену на 200; частоту дихання (ЧД) (відношення 60 c до тривалості поточного спіроциклу); швидкість повітряного потоку на вдиху $\left(\mathrm{V}_{\mathrm{vd}}\right)$ та видиху $\left(\mathrm{V}_{\mathrm{vud}}\right)$; прискорення повітряного потоку на вдиху $\left(\mathrm{A}_{\mathrm{vd}}\right)$ та види$\mathrm{xy}\left(\mathrm{A}_{\text {vud }}\right)$ з приведенням їх до умов BTPS.

Для отримання графіка прискорення диференціювали 3 кроком 5 мс криву швидкості повітряного потоку. Динаміку змін показників упродовж проби визначали шляхом розрахунку їх середніх значень за проміжки часу на 1-3 c, 4-6 с та 7-9 с від іï початку.

Обчислення середніх значень, їх помилок, коефіцієнтів варіації проводили в електронних таблицях Excel 2003. Зв'язок між різними показниками та ступінь відтворюваності при повторних вимірюваннях оцінювали за непараметричним коефіцієнтом кореляції Спірмена у програмі Statistica-5.

Результати та їх обговорення. 3 метою визначення валідності використання спірографічних показників при тесті МВЛ без та 3 додатковим опором диханню для оцінки функціонального стану веслувальників проводили їх порівняння з рівнем, досягнутим неспортсменами. Майже за всіма розрахованими параметрами веслувальники показали вищі результати, ніж неспортсмени, як без, так і з додатковим опором вдиху та видиху. Привертає увагу, що за ЧД під час тесту без додаткового опору диханню різниць між I та II групами не спостерігалось, а при додатковому опорі у спортсменів відмічався значно більший 
приріст цього показника, ніж у неспортсменів. При пробі МВЛ з опором вдиху відсотки відмінностей між групами за $\mathrm{V}_{\text {vud }}, \mathrm{A}_{\mathrm{vd}}, \mathrm{A}_{\mathrm{vud}}$, ХОД були майже такими, як при традиційному проведенні тесту. В той же час при пробі з додатковим опором видиху відсоток відмінностей між групами обстежуваних виявився меншим. Це, ймовірно, пояснюється спрямованістю тренувального процесу спортсменів-веслувальників на розвиток інспіраторних м'язів. При проведенні тесту з додатковим опором диханню найменш інформативним був показник швидкості повітряного потоку на вдиху, котрий у групах обстежуваних не відрізнявся.

Аналіз динаміки спірографічних показників в обох групах упродовж тесту показав, що без додаткового опору медіани відсотка змін на 7-9 секундах, порівняно $з$ 1-3 секундами, не відрізнялись. За умов опору вдиху у спортсменів спостерігалось, на перший погляд, парадоксальне вірогідно більше, порівняно 3 неспортсменами, зниження майже всіх аналізованих показників. У неспортсменів їх значення впродовж тесту, навпаки, збільшувались. Це може свідчити про більш швидке впрацьовування дихальних м'язів у веслувальників на початку навантаження. При виконанні МВЛ з додатковим опором на видиху у спортсменів вірогідно більшим було зниження тільки $\mathrm{A}_{\text {vud }}$ (відповідно - 6,7 \% та 3,8 \%).

Для визначення надійності оцінки функціонального стану спортсменів за допомогою запропонованих показників здійснювали їх кореляційний аналіз при повторних вимірюваннях ( $=56)$.

При традиційному проведенні тесту МВЛ майже за всіма характеристиками функціонування системи зовнішнього дихання не встановлено вірогідних зв'язків, а виявлені достовірні зв'язки вказують на низький ступінь відтворюваності. Відтворюваність аналізованих показників та їх динаміки при виконанні тесту з додатковим опором вдиху у більшості випадків була вірогідною і спостерігались в основному зв'язки середнього рівня (с від 0,5 до 0,6). При застосуванні додаткового опору видиху спостерігалась подібна повторюваність ЧД, ХОД, $\mathrm{V}_{\mathrm{vud}}, \mathrm{A}_{\mathrm{vd}}$ та відсутність зв язків між рівнями показників динаміки змін упродовж тесту. Отже, найбільш надійними $є$ показники, отримані під час проведення тестів МВЛ з опором вдиху та видиху.

Детальний аналіз спірографічних показників при тесті МВЛ без і з додатковим опором диханню може надати нову інформацію відносно функціонального стану системи зовнішнього дихання у спортсменів. Також доцільно аналізувати динаміку впрацьовування системи зовнішнього дихання при МВЛ з опором вдиху.

Висновки. 1. Доведена можливість використання детального аналізу спірографічних показників та їх динаміки впродовж тесту максимальної вентиляції легенів без та з опором диханню у спортсменів.

2. Встановлено більш високий рівень надійності оцінки резервних можливостей зовнішнього дихання при використанні тесту максимальної вентиляції легенів $з$ додатковим опором вдиху та видиху, порівняно з стандартним його виконанням.

3. У подальшому пропонується використання описаних методик в інженерному рішенні при вимірюванні та оцінці резервних можливостей системи зовнішнього дихання у спортсменів різної спеціалізації та за різних умов.

performance after exhaustive endurance exercise / C. Perret, R Pfeiffer, U. Boutellier [et al.] // Eur. Respir. J. - 1999. - Vol. 14, №2. - P. 264-269.

7. Do maximum flow-volume loops collected during maximum exercise test alter the main cardiopulmonary parameters? / M. Bussotti, P. Agostoni, A. Durigato [et al.] // Chest. - 2009. Vol. 135, №2. - P. 425-433.

8. Способ оценки резервных возможностей организма человека [Текст]: Патент 2195858 Рос. Федерация: МПК7 А61В5/02 / Воронков Д. В., Соколов А. В., Баландин Ю. П., Лабутин Г. И.; заявитель и патентообладатель ООО "Центр медицинской профилактики "Валеомед". - № 99108795/14; заявл. 06.05.1999; опуб. 10.01.2003.

9. Спосіб діагностування типу і ступеня тяжкості дихальної недостатності [Текст]: Пат. 23019 Україна: МПК7А61В 5/09 / Воронко А. А.; заявник та патентовласник Воронко А. А. - u200608338, заявл. 25.07.2006; опуб. 10.05.2007, Бюл. № 6. 